make this collection a worthy sign that St. Jane has given medieval feminist history and literary study much to be thankful for.

Elizabeth Hodgson

University of British Columbia

\title{
William J. Bulman and Robert G. Ingram, eds., God in the Enlightenment (Oxford: Oxford University Press, 2016). 322pp. Hardcover $\$ 99.00$.
}

This important collection of essays aims to address an irksome topic from an intriguing perspective, one that, so the editors hope, might help to heal the unfortunate impasse in the current debate between "liberals" and "communitarians" over the virtues or vices of the so-called Enlightenment project. The volume's main target is the well-known genealogy of the Enlightenment famously furnished by D'Alambert, who painted the Renaissance as preparing the ground for the Reformation which, in turn, made the Scientific Revolution possible. It was thus, according to this view, that the seventeenth century began the relentless destruction of what eighteenth-century philosophes would refer to as "the system," a quaint euphemism for Aristotelianism and the way in which Christian apologists had chosen to deploy it. Those who accept this view usually define the Enlightenment, to quote one of its most eloquent modern exponents, as "the broadly secular, experimental, individualistic, and progressive intellectual world ... in which the old and apparently unassailable forms of association, of belief and tradition, which had for centuries divided human beings into mutually suspicious and often brutally homicidal groups, were slowly and painfully, but irreversibly, abandoned" (Anthony Pagden, The Enlightenment and Why it Still Matters, 2013).

Like all neat historical explanations, this one can be readily questioned. The Renaissance and the Reformation did not inevitably lead to secularism. Indeed, the seventeenth century was an intensely religious age during which the materialism of a Hobbes or the monism of a Spinoza weighed light against the overwhelming mass of theologians and preachers who were almost solely responsible for popular instruction. Even in the eighteenth century, the increasing prestige and influence of the culture of the Enlightenment owed a great deal to the wide channels of international diffusion that it had acquired among the educated elites but which rarely reached the rest of the population. It is easy to forget that the vast majority of people in eighteenth-century Europe still lived in economically self-contained regional units with their own laws and institutions, that Voltaire and Bolingbroke were the contemporaries of Wesley and St Paul of the Cross, and that Gibbon and Adam Smith composed their great works at the same time as St Benedict Joseph Labre led the life of a medieval ascetic and widely admired miracle worker.

All the essays in this collection tap various aspects of this strangely neg- 
lected reality. In the process, they demonstrate that none of the traits that traditional scholarship associates with the Enlightenment led to secularism with any degree of consistency. To pretend that this was the case, Bulman argues, is to mistake "an essentially political movement for an intellectual one" (6) and to fall foul of what the philosopher Charles Taylor has called "subtraction"- - the inability, or unwillingness, to accept that the rise of secularism needs to be understood within (not in opposition to) the complex transformations in contemporary theological and metaphysical debates. The task is made all the more complex by the unfortunate fact that practically all the revisionist studies that have emerged in recent years fail to avoid some degree of "subtraction," with the regrettable result that they have tended to remain largely unaware of each other. The long-term need, therefore, is one of integration and consolidation from a twofold perspective. The first should attempt to reassess the religious dimensions of the early Enlightenment (c. 1650-1715). The second should aim to avoid the persistent tendency to envisage religion through the distorting lens of an enlightened, or post-enlightened, understanding of it.

God in the Enlightenment is much more successful in the first than in the second of these much-needed reassessments. As far as the first one is concerned, no reader of this valuable collection will be left in any doubt that the traditional view of the period as a radical break with the past is not merely misleading but fundamentally erroneous. In a kaleidoscopic array of essays ranging in topic from Hobbes and Spinoza to Leibniz and Kant and from Hinduism to pre-Hispanic Andean religions, the resilience of the Renaissance and the Reformation is everywhere in evidence. God not only survived but seemed to thrive in an environment that we have grown accustomed to conceiving as characteristically individualistic and libertarian but which was just as often, and just as vigorously, communitarian and authoritarian. Yet, as far as the second reassessment in concerned, with the partial exception of the essay by Brad S. Gregory, the distorting lens of enlightened and post-enlightened understandings of God is, unfortunately, rarely removed. If God survived the Enlightenment, we are told, he did not survive in unaltered form. The period, writes Dale K. Van Kley, "drew real blood and put the Christian Trinitarian God on the defensive" (310). In the process, writes Bulman, "the thrust of the Enlightenment was to rescue God from ancient philosophy and its first great Christian ally, Augustine" (27). Paul C. H. Lim concurs: "a distinct tendency within the theology of the Enlightenment," he tells us, "was a frontal assault on Augustinian conceptions of the 'self-determination of reason and the autonomy of the moral will,' viz., original sin and predestination and their impact on divine sovereignty and human freedom" (137).

Surprising as it may sound, none of these notions are ones that the real Augustine would even remotely have recognised. They all derive from a peculiarly early modern conflation of nominalism in philosophy and voluntarism in theology, exacerbated by the hardening of confessional divisions during the Reformation, which furnished the modern world with an essentially idolatrous understanding of 
the divinity as a sublime mechanic who not only inhabited the universe but who also needed to be defended by thinkers increasingly immersed in the problem of "theodicy." To see this tradition as characteristic of "the ancient and medieval perception of the supernatural," as Joan-Pau Rubiés asserts in an otherwise exceptionally illuminating essay (130), is an unfortunate misconception that will do little to help overcome what Bulman describes as "an intrinsically intractable and inappropriate debate that has, ironically enough, taken on the character of a confessional conflict" (31).

Fernando Cervantes

University of Bristol

\section{Robeson Taj Frazier, The East is Black: Cold War China in the Black Radical Imagination (Durham: Duke University Press, 2014). 328pp. Paper- back $\$ 26.95$.}

The East is Black by the African American studies and media studies scholar Robeson Taj Frazier is a cutting-edge book which succeeds both as theory and as history. Interdisciplinary and well-written, this monograph provides brilliant insight into the possibilities and limitations of black radical global imaginaries through an examination of black American encounters with Communist China from 1949 to 1976. The author vividly traces the travels, writing, and teaching in the People's Republic of China (PRC) of the preeminent black scholar W.E.B. Du Bois, playwright and activist Shirley Graham Du Bois, journalist William Worthy, freedom fighters Robert F. Williams and Mabel Williams, and Marxist feminist Vicki Garvin during the height of the global Cold War. Frazier's book distinguishes him as an important new voice on black radicalism, black internationalism, the Cold War, and Afro-Asian encounters, in the vein of Fred Ho, Vijay Prashad, Diane Fujino, Gerald Horne, Bill Mullen, and Judy Tzu-Chun Wu.

The book takes the first part of its title from a Chinese opera and song "Dong Hong" ("The East is Red"). The song briefly served as the Chinese national anthem during the 1960s and it captured the revolutionary elan of the PRC. Framing itself as the champion of formerly colonized people of colour and as an opponent of the United States and the Soviet Union, China under Mao Zedong - the revolutionary, chairman of the Chinese Communist Party, and founder of the PRC in 1949-publicly supported African American liberation struggles and Third World solidarity during the 1950s and 1960s. This stance captured the imagination of black radicals - they viewed Jim Crow and anti-black violence at home as the Achilles Heel of U.S. Cold War global policy that sought to win the hearts and minds of emerging Third World nations against communism. For black American radicals, China symbolized freedom and international solidarity. For these reasons, they came to see the PRC for themselves—-the Du Boises and William Worthy sojourned to 